\title{
A new species of nine-spined stickleback, Pungitius modestus (Gasterosteiformes, Gasterosteidae), from northern Honshu, Japan
}

\author{
TATSUYA MATSUMOTO ${ }^{1,2,5}$, KEIICHI MATSUURA ${ }^{3} \&$ NAOTO HANZAWA $^{4}$ \\ ${ }^{1}$ Graduate School of Science and Engineering, Yamagata University, 1-4-12 Kojirakawa-machi, Yamagata, 990-8560, Japan \\ "ZZmta31s@gmail.com; @ ittps://orcid.org/0000-0002-3809-0000 \\ ${ }^{2}$ Present address: The United Graduate School of Agricultural Sciences, Kagoshima University, 1-21-24 Korimoto, Kagoshima 890- \\ 0065, Japan \\ ${ }^{3}$ Division of Fishes, National Museum of Nature and Science, 4-1-1 Amakubo, Tsukuba, Ibaraki 305-0005, Japan \\ (1) https://orcid.org/0000-0002-7694-8549 \\ ${ }^{4}$ Faculty of Science, Yamagata University, 1-4-12 Kojirakawa-machi, Yamagata, 990-8560, Japan \\ (1) https://orcid.org/0000-0002-8835-2611 \\ ${ }^{5}$ Corresponding author
}

\begin{abstract}
A new species of nine-spined stickleback, Pungitius modestus, is described based on the holotype and 17 paratypes (38.7-51.7 mm standard length) collected from the inland area of Yamagata Prefecture, northern Honshu, Japan. The new species is distinguished from the other species of Pungitius by the following combination of characters: 30-32 small unconnected lateral plates; dorsal-fin rays VIII-X (usually IX)+9-11; anal-fin rays 7-10 (usually 8); pectoral-fin rays 10; a short spiny dorsal fin base $(26.5 \%-29.8 \% \mathrm{SL})$; the first spiny dorsal fin spine behind the pectoral-fin base; a long preanal fin $(59.9 \%-67.4 \% \mathrm{SL})$; the anal-fin spine below the 1 st-3rd dorsal-fin rays; a short pelvic-fin spine $(6.3 \%-9.1 \% \mathrm{SL})$; a short anal-fin spine $(4.1 \%-6.0 \% \mathrm{SL})$; a long caudal peduncle $(14.3 \%-19.7 \% \mathrm{SL})$; no body markings; membranes of the dorsal-fin spines dark brown with black pigments; the entire male body, and soft dorsal and anal fins, becoming black in the breeding season; the anteroventral process of the ectocoracoid present; and the dorsal extension of the ascending process of the pelvis level with the dorsal-most actinost.
\end{abstract}

Key words: Gasterosteidae, nine-spined stickleback, new species, Yamagata Prefecture, northern Japan

\section{Introduction}

Fishes of the genus Pungitius Coste, 1848 (Gasterosteiformes, Gasterosteidae), generally known as nine-spined sticklebacks, are widely distributed in fresh and brackish waters in Eurasia and North America (Keivany \& Nelson, 2000). Similar in general appearance to three-spined sticklebacks of the genus Gasterosteus Linnaeus, 1758, the nine-spined sticklebacks differ in having more dorsal-fin spines (V-XIII) and a more slender body (Wootton 1976; Keivany \& Nelson 2000). Nine-spined sticklebacks also differ from three-spined sticklebacks in nest-building behavior. Nests of nine-spined sticklebacks consist of a bundle of fine fragments of vegetation, forming a mass about 4 $\mathrm{cm}$ in diameter and positioned among the branches and leaves of aquatic vegetation (Wootton 1976, Chae and Yang 1993). Those of three-spined sticklebacks, however, are built on the substrate of rivers and lakes (Wootton 1976). The genus Pungitius is currently represented by 11 species (Fricke et al. 2020), as follows: P. pungitius (Linnaeus, 1758), nearly circumboreal; P. laevis (Cuvier, 1829), in the Seine, Scheldt and Loire basins (France); P. vulgaris (Mauduyt, 1848), in the Loire, Gironde and Dordogne basins (France); P. platygaster (Kessler, 1859), in the Black, Caspian and Aral Sea basins; P. sinensis (Guichenot,1869), in the Kuril Islands, Kamchatka, and southward to the Tumannaya River (China); P. stenurus (Kessler, 1876), in northern China and Mongolia; P. bussei (Warpachowski in Warpachowski \& Herzenstein, 1888), in the Amur River basin (Russia); P. tymensis (Nikolskii, 1889), in Russian Far East and Japan; P. kaibarae (Tanaka, 1915), in Japan, Korea, and Russian Far East; P. hellenicus (Stephanidis, 1971), in Greece; and P. polyakovi (Shedko et al. 2005), in Sakhalin Island (Russia). However, the taxonomy of 
species found in Europe and East Asia has not yet to be clarified (Keivany \& Nelson 2000; Takahashi et al. 2001, 2016; Denys et al. 2018; Wang et al. 2015).

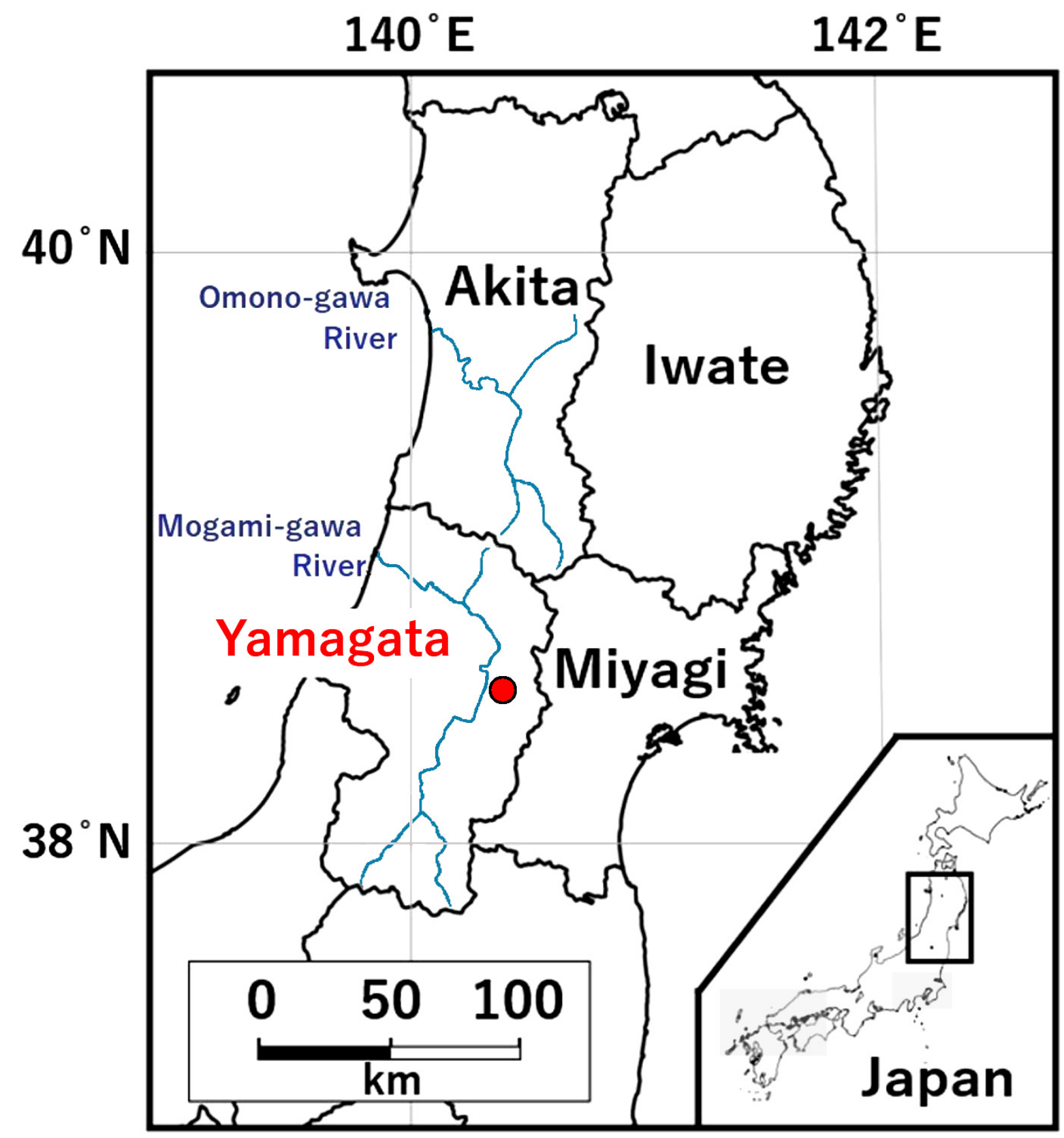

FIGURE 1. Map showing the type locality (solid circle) of Pungitius modestus, sp. nov.

Over the past few decades, the nine-spined sticklebacks of Japan have been extensively studied using morphological, ecological and/or molecular approaches (e.g., Ikeda 1933; Takata et al. 1987a, b; Meguro et al. 2016; Takahashi et al. 2016). These studies resulted in the recognition of several Pungitius "types" such as freshwater and brackish water types (Takata et al. 1987a, b, Takahashi et al. 2001, and Hosoya 2013), and Omono type (Takata et al. 1987b, Takahashi et al. 2001, Hosoya 2013). Although most authors recognized these "types" as biological species, they have not yet been given scientific names. Takahashi et al. (2016) showed that the fish referred to in the Japanese literature as "the Omono type" was composed of two separate clades, one found in the Mogami-gawa River system in Yamagata Prefecture (Fig. 1), and the other in the Omono-gawa River system in Akita Prefecture. They also clarified that the two lineages of the Omono type were genetically closely related to P. kaibarae in Korea and Russia, though clearly differentiated from the latter. Before Takahashi et al. (2016) published a molecular 
phylogenetic analysis of the Pungitius found in East Asia, Wang et al. (2015) included the Omono type from Akita Prefecture in their molecular phylogenetic analysis of Pungitius. Although they did not study the other population in Yamagata Prefecture, they showed that the clade of the Omono type in Akita Prefecture was clearly differentiated from the other species of Pungitius. The lineage of nine-spined stickleback distributed in Yamagata Prefecture is restricted to only a few inland locations (Hosoya 2013; Hanzawa et al. 2019).

The main aim of this paper is to describe the nine-spined stickleback found only in the Mogami-gawa River system as a new species under the name Pungitius modestus, with a description of its distinguishing characteristics. We also compare the new species with all known species of Pungitius based on examination of available type specimens and the original descriptions of the previously described species. Because populations of P. modestus, sp. nov. are found in only a few places in the inland area of Yamagata Prefecture, it has been listed as an endangered species (Hanzawa et al. 2019). In terms of conservation policy, it is urgently necessary to give scientific names to threatened and undescribed species. This is why we focus on describing and naming the nine-spined stickleback of Yamagata Prefecture. Although other authors have suggested the presence of other undescribed nine-spined sticklebacks in Japan, we do not address these because they are being studied by other researchers.

\section{Materials and methods}

The specimens used in this study were deposited in the following institutions: Natural History Museum, London (BMNH); Muséum National d'Histoire Naturelle, Paris (MNHN); Department of Zoology, National Museum of Nature and Science, Tsukuba (NSMT); Yamagata Prefectural Museum, Yamagata (YAMA); Yamagata University Museum, Yamagata (YUMB); Zoological Institute, Russian Academy of Sciences, St. Petersburg (ZIN); and University Museum, The University of Tokyo, Tokyo (ZUMT). Counts and measurements generally followed the methods of Hubbs \& Lagler (1964), with the following exceptions: body depth, measured as the largest distance between the dorsal and ventral body contours just in front of the pelvic-fin origin, and oblique body depth, measured as the distance between the origins of the soft dorsal and anal fins. Standard, total, and head lengths are abbreviated as SL, $\mathrm{TL}$, and HL, respectively. Considering changes in body shape with growth, specimens longer than $35 \mathrm{~mm}$ SL were selected for analysis, although Denys et al. (2018) used those longer than $30 \mathrm{~mm}$ SL. Osteological descriptions and illustrations were based on a paratype (NSMT-P 140554, $40.5 \mathrm{~mm} \mathrm{SL}$ ) cleared and double-stained according to the protocol of Kelly and Bryden (1983). Measurements were made with calipers to the nearest $0.1 \mathrm{~mm}$. Radiographs were used to count the number of fin rays. Counts and measurements of the holotype are given first, followed by those of the paratypes in parentheses. Characteristics described in the Diagnosis are not repeated in the Description. For ease of assimilation in Japan, the word "type", such as in "Omono type", refers to a morph, especially as used in the Japanese literature, and not as generally understood in zoological nomenclature.

\section{Pungitius modestus, sp. nov.}

New Japanese name: Kakure-tomiyo (Figure 2a).

Pungitius sp. 3 (in part) Hosoya, 2013: 607.

Holotype. NSMT-P 133674, 45.4 mm SL, tributary of Mogami-gawa River, Tendo, Yamagata Prefecture, Japan, 30 October 2014, collected by R. Sato and N. Hanzawa.

Paratypes. 17 specimens in total. 8 specimens, 39.7-48.4mm SL, tributary of Mogami-gawa River, Tendo, Yamagata Prefecture, Japan, NSMT-P 133670, NSMT-P 133671, NSMT-P 133672, NSMT-P 133673, 30 October 2014; NSMT-P 133676, 2 November 2018; NSMT-P 136595, NSMT-P 136596, NSMT-P 136597, 26 March 2020. 7 specimens, 43.6-51.7mm SL, small pond connected to Mogami-gawa River, Tendo, Yamagata Prefecture, Japan, NSMT-P 133667, NSMT-P 133668, NSMT-P 133669, 22 October 2014; NSMT-P 133675, NSMT-P 133677, 7 July 2018; NSMT-P 133678, 22 October 2014; NSMT-P 133679, 22 October 2014. 2 specimens, 38.7-40.5mm SL, small pond connected to Mogami-gawa River, Higashine, Yamagata Prefecture, Japan, NSMT-P 140553, NSMT-P 140554, 29 September 2020. 
Non-type material. YAMA 3Pi000564, 3 specimens, 43.9-49.9 mm SL, small river connected to Mogamigawa River, Higashine, Yamagata Prefecture, Japan, 21 February 1973; YAMA 3Pi000566, 3 of 4 specimens, 38.4$49.9 \mathrm{~mm}$ SL, locality same as the holotype, 18 September 1985; YAMA 3Pi000567, 1 of 2 specimens, $42.9 \mathrm{~mm}$ SL, tributary connected to Mogami-gawa River, Higashine, Yamagata Prefecture, Japan, 20 June 1973; YUMB I-1-9, 7 specimens, 39.8-57.0 $\mathrm{mm}$ SL, locality same as the preceding, collection date unknown.

Comparative material. Gasterosteus platygaster Kessler, 1859, syntypes, BMNH 1897.7.5.2, 2 specimens, 39.3-44.4 mm SL; Gasterosteus sinensis Guichenot, 1869, syntypes, MNHN-IC-0000-5228, 7 specimens, 21-26 mm SL; Gasterosteus stenurus Kessler, 1876, syntypes, ZIN 2471, 5 specimens, 46-55 mm SL; Gasterosteus bussei Warpachowski, 1888, syntypes, ZIN 7100, 4 specimens 42-53 mm SL; Gasterosteus tymensis Nikolskii, 1889, syntype, BMNH 1892.4.28.1, 58.5 mm SL; Pygosteus kaibarae Tanaka, 1915, ZUMT 8197, holotype, 45.0 mm SL, Kyoto, Japan; 7 paratypes, 29.4-45.0 mm SL, ZUMT 59848-59854, collection data same as the holotype; NSMTP 29878, 10 non-type specimens, 35.0-40.7 mm SL, Kyoto, Japan; YAMA 3Pi000592, 3 non-type specimens, 38.1-41.7 mm SL, Kyoto, Japan; NSMT-P 140555, non-type specimens, 30.8 mm SL, Gangneung, Gangwon-do, Korea; NSMT-P 140556, $31.8 \mathrm{~mm}$ SL, collection data same as the preceding; NSMT-P 140557, $31.4 \mathrm{~mm}$ SL, collection data same as the preceding.

Diagnosis. Pungitius modestus is distinguished from other species of Pungitius by the following combination of characters (see also Remarks): dorsal-fin rays IX (VIII-IX)+9 (9-11); pectoral-fin rays 10 (10); 30 (30-32) small unconnected lateral plates running from just behind the dorsal end of the gill opening to the caudal peduncle (Fig. $2 \mathrm{~b}$ ); keel on the caudal peduncle present; dorsal-fin spine inclining alternately to left and right of the mid-line; dorsal, pelvic and anal-fin spines short, 3.6\% (2.7\%-4.9\%) SL, 7.4\% (6.3\%-9.1\%) SL and 5.0\% (4.1\%-6.0\%) SL, respectively; base of the spiny dorsal fin short, $28.7 \%(26.5 \%-29.8 \%)$ SL; first dorsal-fin spine located above or slightly behind the pectoral-fin base; anal-fin spine located below the 1st (1st-3rd) dorsal-fin ray; ascending process of the pelvis relatively developed and extending dorsally to the level of the dorsal-most actinost (Fig. 3a); anteroventral process of the ectocoracoid present, right and left ectocoracoids articulating with each other at the anterior end (Fig. 3b); and membranes of the dorsal-fin spines dark brown with many black pigments.
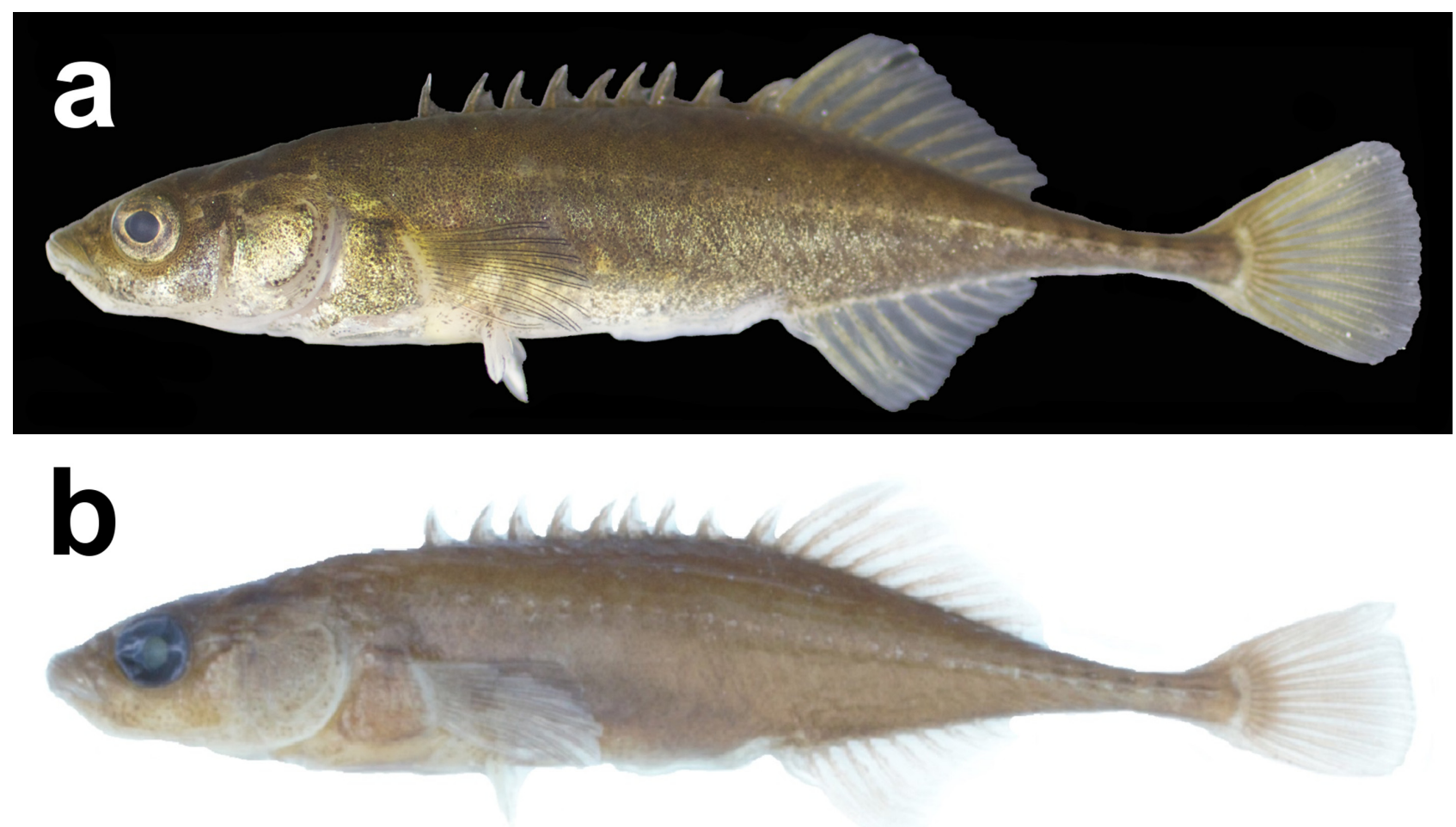

FIGURE 2. a) Freshly dead holotype of Pungitius modestus, sp. nov., NSMT-P 133674, female, 45,4 mm SL, Tendo, Yamagata Prefecture, Honshu, Japan. b) Holotype preserved in 70\% ethanol. 

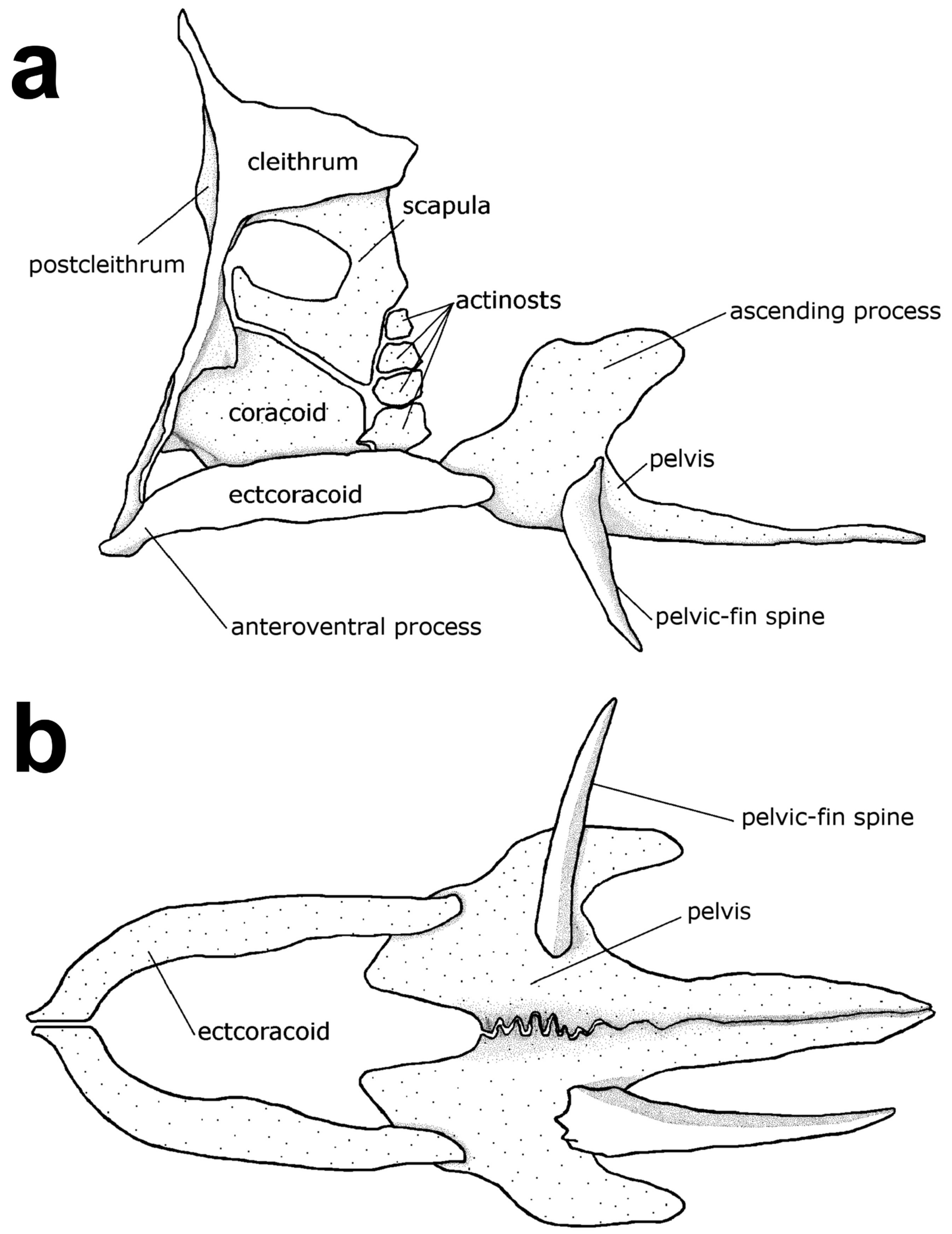

FIGURE 3. Pectoral and pelvic girdles of Pungitius modestus, sp. nov., paratype, NSMT-P 140554, male, 38.7 mm SL, Higashine, Yamagata Prefecture, Honshu, Japan. a) Lateral view. b) Ventral view. 
TABLE 1. Frequency distributions of dorsal-fin spines and dorsal-fin soft rays in 12 species of Pungitius. Counts are based on voucher specimens in BMNH, MNHN, NSMT, YAMA, YUMB, ZIN and ZUMT, and data provided by Keivany et al. (1997) $)^{1}$, Denys et al. (2018) $)^{2}$ and Shedko et al. (2005) ${ }^{3}$. Counts of P. modestus, sp. nov. and P. kaibarae come from non-type as well as type specimens.

\begin{tabular}{|c|c|c|c|c|c|c|c|c|c|c|c|c|}
\hline & \multicolumn{12}{|c|}{ Dorsal-fin spines } \\
\hline & II & III & IV & V & VI & VII & VIII & IX & $X$ & XI & XII & XIII \\
\hline P. modestus, sp. nov. & & & & & & & 7 & $21^{*}$ & 2 & & & \\
\hline P. bussei & & & & & & & $1^{*}$ & $3^{*}$ & & & & \\
\hline P. hellenicus ${ }^{1}$ & 1 & 4 & 9 & 5 & 1 & & & & & & & \\
\hline P. kaibarae & & & & & & & $17^{*}$ & 4 & & & & \\
\hline P. laevis ${ }^{2}$ & & & & & & & $14^{*}$ & 9 & 1 & & & \\
\hline P. platygaster ${ }^{1}$ & & & & & & & 7 & $16^{*}$ & 3 & & & \\
\hline P. polyakovi ${ }^{3}$ & & & & & & & 1 & 20 & 115 & 26 & & \\
\hline P. pungitius ${ }^{2}$ & & & & & & & 4 & 8 & 11 & 1 & & \\
\hline P. sinensis ${ }^{3}$ & & & & & & & 17 & $141^{*}$ & 27 & & & \\
\hline P. stenurus & & & & & & & $4^{*}$ & $1^{*}$ & & & & \\
\hline P. tymensis ${ }^{3}$ & & & & & & & & & 13 & 97 & $86^{*}$ & 14 \\
\hline P. vulgaris ${ }^{2}$ & & & & & & & 11 & $11^{*}$ & 2 & & & \\
\hline
\end{tabular}

*Name bearing types

TABLE 1. (Continued)

\begin{tabular}{|c|c|c|c|c|c|}
\hline & \multicolumn{5}{|c|}{ Dorsal-fin rays } \\
\hline & 8 & 9 & 10 & 11 & 12 \\
\hline P. modestus, sp. nov. & & $7^{*}$ & 19 & 6 & \\
\hline P. bussei & \multicolumn{5}{|c|}{ Not available } \\
\hline P. hellenicus ${ }^{1}$ & \multicolumn{5}{|c|}{ Not available } \\
\hline P. kaibarae & 1 & $6^{*}$ & 11 & 3 & \\
\hline P. laevis ${ }^{2}$ & 4 & 8 & 8 & $4^{*}$ & \\
\hline P. platygaster ${ }^{1}$ & & $2^{*}$ & & & \\
\hline P. polyakovi ${ }^{3}$ & \multicolumn{5}{|c|}{ Not available } \\
\hline P. pungitius ${ }^{2}$ & 1 & 3 & 11 & 7 & 2 \\
\hline P. sinensis ${ }^{3}$ & & & $5^{*}$ & & \\
\hline P. stenurus & & $2^{*}$ & $1^{*}$ & $2^{*}$ & \\
\hline P. tymensis ${ }^{3}$ & & & & $1^{*}$ & \\
\hline P. vulgaris ${ }^{2}$ & 1 & 11 & $11^{*}$ & 1 & \\
\hline
\end{tabular}

*Name bearing types

Description. Counts and morphometric measurements are shown in Tables 1-4. Body elongate and laterally compressed, tapering posteriorly to the caudal peduncle, body depth greatest just in front of the pelvic-fin origin; lateral plates on the side of the body small, oval in shape, unconnected; dorsal profile of the head almost straight, gently ascending from the mouth to dorsal-fin origin, ventral profile slightly convex; mouth small, slightly supraterminal, posterior end of the upper jaw not reaching the level of the anterior edge of the eye; eye large and rounded, diameter $6.2 \%$ SL $(5.7 \%-7.4 \%)$, larger than the caudal peduncle depth; snout conical in lateral view, slightly shorter than the eye diameter; dorsal-fin spines strong and sharply pointed, all fin spines almost equal in length; soft dorsalfin opposite to the anal-fin, all fin rays of soft dorsal and anal-fins branched; pectoral fin fan-shaped, all rays simple; pelvic-fin composed of 1 short spine and 1 (1-2) soft ray; anal-fin composed of 1 short spine and 8 (7-9) rays; caudal-fin slightly rounded with 12 (11-13) rays composed of 10 (9-11) branched rays, and simple dorsal- and ventralmost rays; ectocoracoid located on the ventral side of the pectoral girdle, curving antero-mesially to articulate with its opposite element; anterior side of the pelvic girdle articulating with the posterior end of the ectocoracoid. 
Color of fresh specimens. Dorsal and lateral sides of the head and body dark brown with a yellowish tinge, ventral side silvery white (Figs. 2a, 4a); membranes of dorsal-fin spines dark brown with many black pigments (Fig. 2a); pectoral-fin hyaline; soft dorsal, anal, and caudal fins with yellowish brown rays and commonly hyaline membranes; pelvic-fin spine and membrane white; in the breeding season, male body and dorsal, anal and pelvic fins black (Fig. 4b), female body light brown with numerous dark brown blotches and spots (Fig. 4c).

Color in preservation. Dorsal and lateral surfaces of the head and body dark brown, ventral side light brown (Fig. 2b).

Distribution. Pungitius modestus is distributed in the inland area of Yamagata Prefecture in northern Honshu, Japan. This species was recorded from the northeastern area of Yamagata Prefecture in the 1930s by Hashimoto (1938). However, the northeastern population is now thought to have been extirpated because it has not been observed in the area for several decades.

TABLE 2. Frequency distributions of anal-fin and pectoral-fin rays in 12 species of Pungitius. Counts are based on voucher specimens in NSMT, YAMA, YUMB and ZUMT, and data provided by Denys et al. (2018) $)^{1}$. Counts of $P$. modestus, sp. nov. and P. kaibarae come from non-type and type specimens.

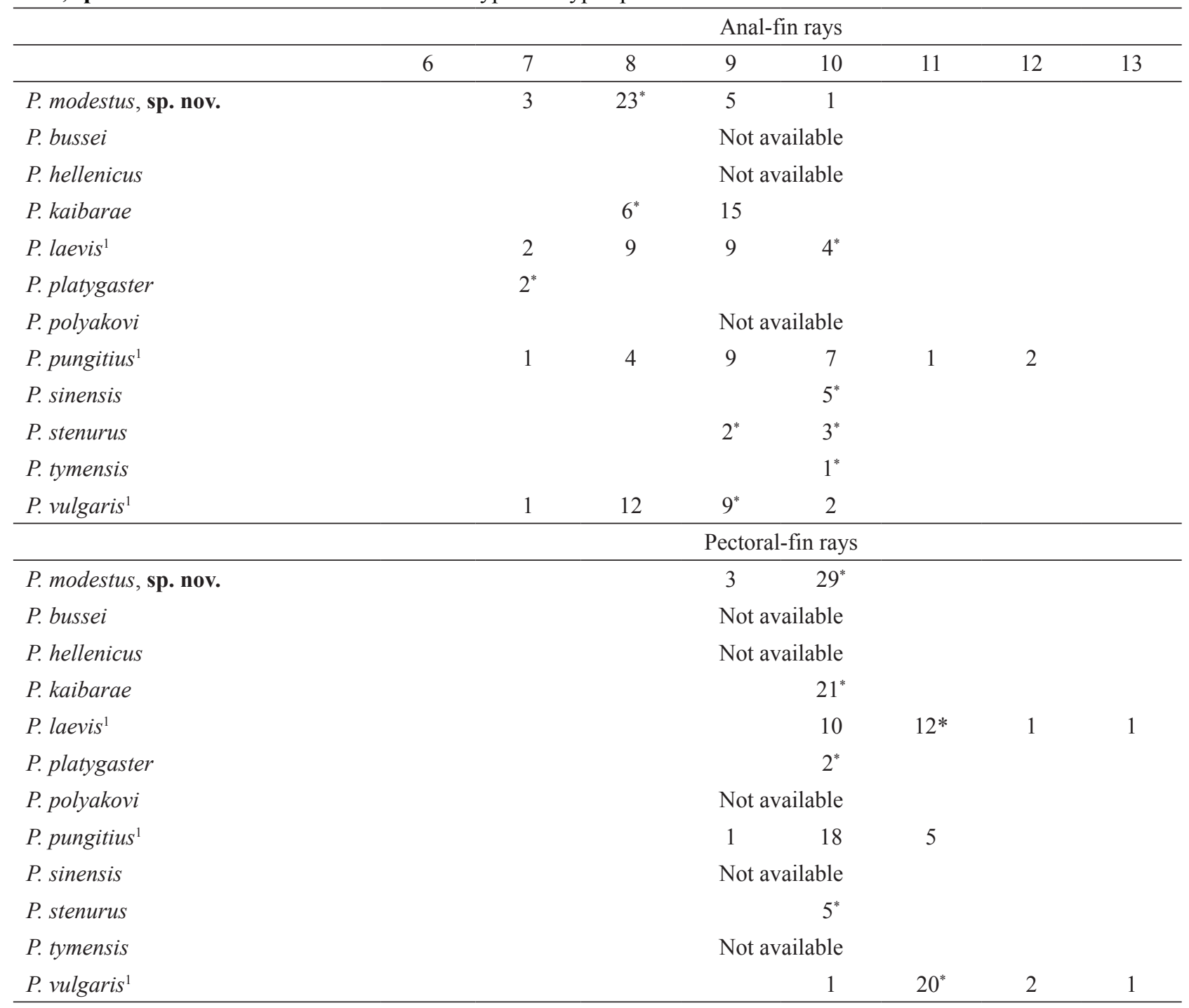

*Name-bearing types

Habitat and biology. Pungitius modestus inhabits small streams and ponds refreshed by abundant cold spring water from the bottom, with temperatures of around $16^{\circ} \mathrm{C}$ throughout the year. Adults feed mainly on amphipods such as Jesogammarus jesoensis (identified by K. Tomikawa), which are extremely abundant in the type locality of $P$. modestus. In contrast, larvae of P. modestus feed on tubificids, and 30-day-old juveniles feed mainly on chironomids and copepods (Kumada et al. in preparation). Pungitius modestus tends to hide in water grasses, and also 
frequently remains still, suspended just above the bottom. The peak of the breeding season is May, with courtship behavior tending to occur at night, although also observed in the daytime. Females usually spawn at night, between $9 \mathrm{pm}$ and dawn (T. Takeda, personal communication).

Etymology. The species name, modestus, refers to its moderate behavior: adults do not fight each other except during the reproductive season. As stated above, Pungitius modestus tends to hide in water grasses, and also frequently remains still just above the bottom. However, other species of Pungitius frequently swim in the water column (Hart 2003, personal observation). The new Japanese name "Kakure-tomiyo" is proposed for the new species. "Kakure" implies its hiding behavior, and "tomiyo" refers to nine-spined sticklebacks.

Remarks. As stated in Introduction, Pungitius is currently represented by 11 species. Below, we describe the differences between these known species and P. modestus.

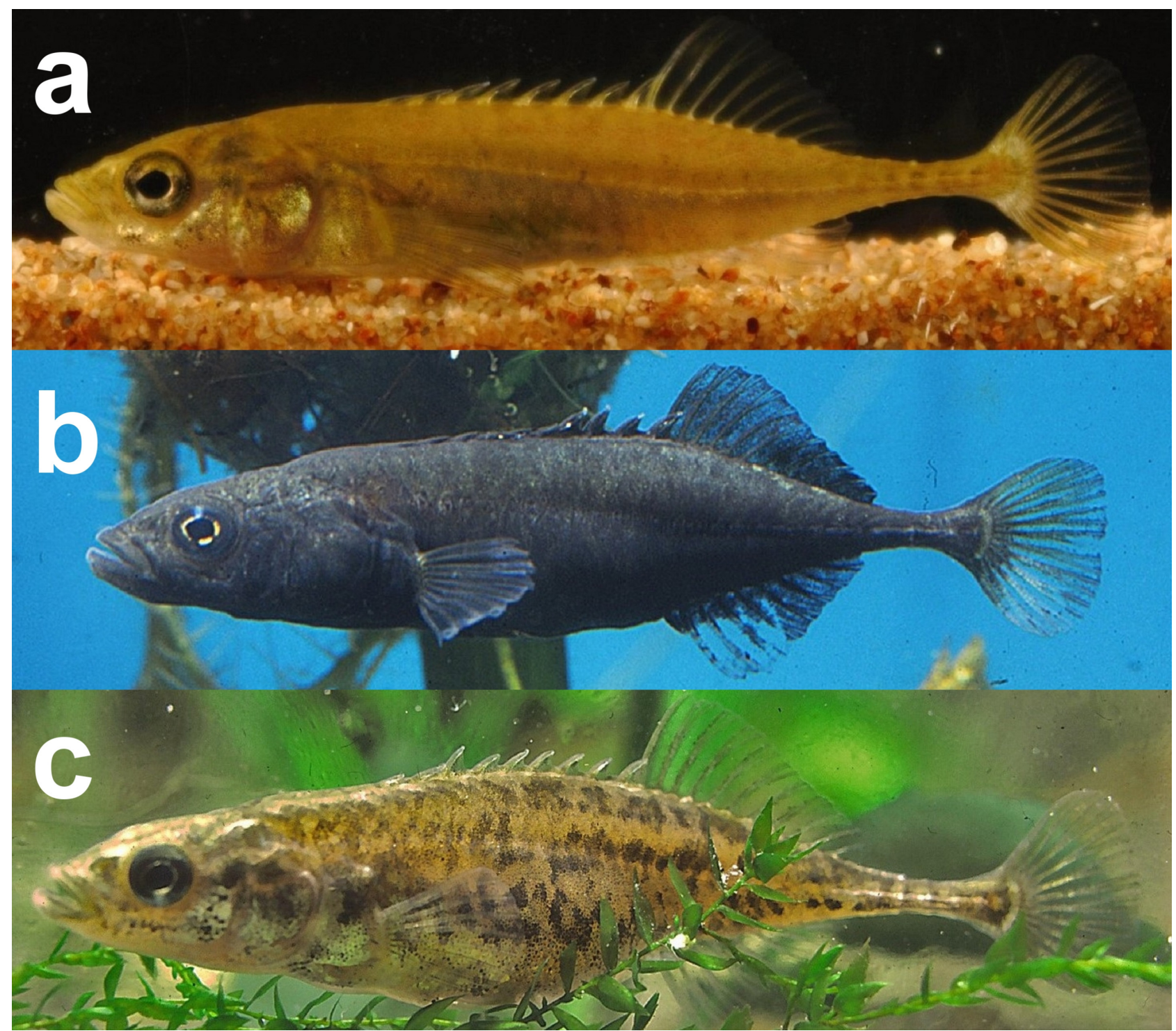

FIGURE 4. a) Living female Pungitius modestus, sp. nov. out of the breeding season. NSMT-P 136597, 41.3 mm SL, Tendo, Yamagata Prefecture, Honshu, Japan. b) Living male in the breeding season (photographed by T. Takeda, May 1992). c) Living female in the breeding season (photographed by T. Takeda, May 1992).

Denys et al. (2018) studied the morphological and genetic characteristics of Pungitius in France, recognizing three valid species: . pungitius, P. laevis, and P. vulgaris. They synonymized P. breviceps (Blanchard, 1866) and P. lotharingus (Blanchard, 1866) with P. laevis, and P. burgundianus (Blanchard, 1866) with P. pungitius. Based on the descriptions and data provided by Keivany \& Nelson (2000), Shedko et al. (2005) and Denys et al. (2018), P. modestus is distinguished from these three valid species as follows: it is distinguished from P. pungitius by the greater number of lateral plates (30-32, vs. 0-12), smaller number of dorsal-fin spines (VIII-X [usually IX], vs. 
VIII-XI [usually X]), and smaller number of anal-fin rays (7-10 [usually 8], vs. 7-12 [usually 9]), the smaller diameter of the eye $(21.1 \%-25.6 \%$, vs. $27.3 \%-33.1 \% \mathrm{HL})$, the lack of markings on the body (vs. brownish gray blotches arranged irregularly), dark brown membranes of spiny dorsal fin (vs. hyaline), and in the breeding season, blackening of the soft dorsal and anal fins of the male (vs. hyaline).

Pungitius modestus differs from P. laevis by the larger number of lateral plates (30-32, vs. 0-4, and only on the caudal peduncle), the lack of markings on the body (vs. blackish blotches), dark brown membranes of spiny dorsal fin (vs. hyaline); and the ascending process of the pelvis, which is relatively well developed and extends dorsally to the level of the dorsal-most actinost (vs. less developed and smaller). The new species differs from P. vulgaris by the larger number of lateral plates (30-32, vs. no lateral plates), a keel on the caudal peduncle (vs. no keel), the smaller number of pectoral-fin rays (9-10 [usually 10], vs. 10-13 [usually 11]), and the smaller diameter of the eye $(21.1 \%-25.6 \%$, vs. $25.3 \%-33.9 \%$ HL).

TABLE 3. Frequency distributions of lateral plates including those on the caudal peduncle of five species of Pungitius. Counts are based on voucher specimens in NSMT, YAMA, YUMB and ZUMT, and data provided by Denys et al. (2018) ${ }^{1}$. Counts of $P$. modestus, sp. nov. and $P$. kaibarae come from non-type and type specimens. Frequency distributions of other species are not available.

\begin{tabular}{|c|c|c|c|c|c|c|c|c|c|c|c|c|c|}
\hline & \multicolumn{13}{|c|}{ Lateral plates } \\
\hline & 0 & 1 & 2 & 3 & 4 & 5 & 6 & 7 & 8 & 9 & 10 & 11 & 12 \\
\hline \multicolumn{14}{|c|}{ P. modestus, sp. nov. } \\
\hline \multicolumn{14}{|c|}{ P. kaibarae } \\
\hline P. laevis ${ }^{1}$ & $16^{*}$ & 4 & 1 & 1 & 2 & & & & & & & & \\
\hline P. pungitius ${ }^{1}$ & 6 & 1 & & & 2 & & 8 & & 3 & 2 & & 1 & 1 \\
\hline P. vulgaris ${ }^{1}$ & $22^{*}$ & & & & & & & & & & & & \\
\hline
\end{tabular}

TABLE 3. (Continued)

\begin{tabular}{|c|c|c|c|c|c|c|}
\hline & \multicolumn{6}{|c|}{ Lateral plates } \\
\hline & 29 & 30 & 31 & 32 & 33 & 34 \\
\hline P. modestus, sp. nov. & & $10^{*}$ & 16 & 6 & & \\
\hline P. kaibarae & 1 & 1 & & $11^{*}$ & 5 & 3 \\
\hline \multicolumn{7}{|l|}{ P. laevis ${ }^{1}$} \\
\hline \multicolumn{7}{|l|}{ P. pungitius ${ }^{1}$} \\
\hline P. vulgaris ${ }^{1}$ & & & & & & \\
\hline
\end{tabular}

*Name-bearing types

Upon our request, James Maclaine of the BMNH kindly provided us with photographs and morphological data of syntypes of Gasterosteus platygaster (Fig. 5). In addition, we included the counts and morphometric data documented in Keivany \& Nelson (2000) and Shedko et al. (2005) for comparisons of Pungitius modestus and $P$. platygaster. Available characteristics differentiate P. modestus from P. platygaster by its lateral plates (small and unconnected, and running from just behind the dorsal end of the gill opening to the posterior side of the caudal peduncle, vs. large connected lateral plates), a keel on the caudal peduncle (vs. no keel), the larger number of dorsal-fin rays (9-11, vs. 6-10), the first dorsal-fin spine above or behind the pectoral-fin base (vs. in front of the pectoral-fin base), and dark brown membranes of spiny dorsal fin (vs. hyaline).

Guichenot (1869) did not provide counts of fin rays in his original description of Gasterosteus sinensis; however, Jonathan Pfliger of MNHN kindly provided us with photographs and counts of G. sinensis syntypes (Fig. 6). The morphological data of the syntypes and those given by Shedko et al. (2005) clearly differentiate Pungitius modestus from P. sinensis by its lateral plates (small and unconnected, and running from just behind the dorsal end of the gill opening to the posterior side of the caudal peduncle, vs. large connected lateral plates), dark brown membranes of spiny dorsal fin (vs. hyaline), and in the breeding season, blackening of the male soft dorsal and anal fins (vs. hyaline). 

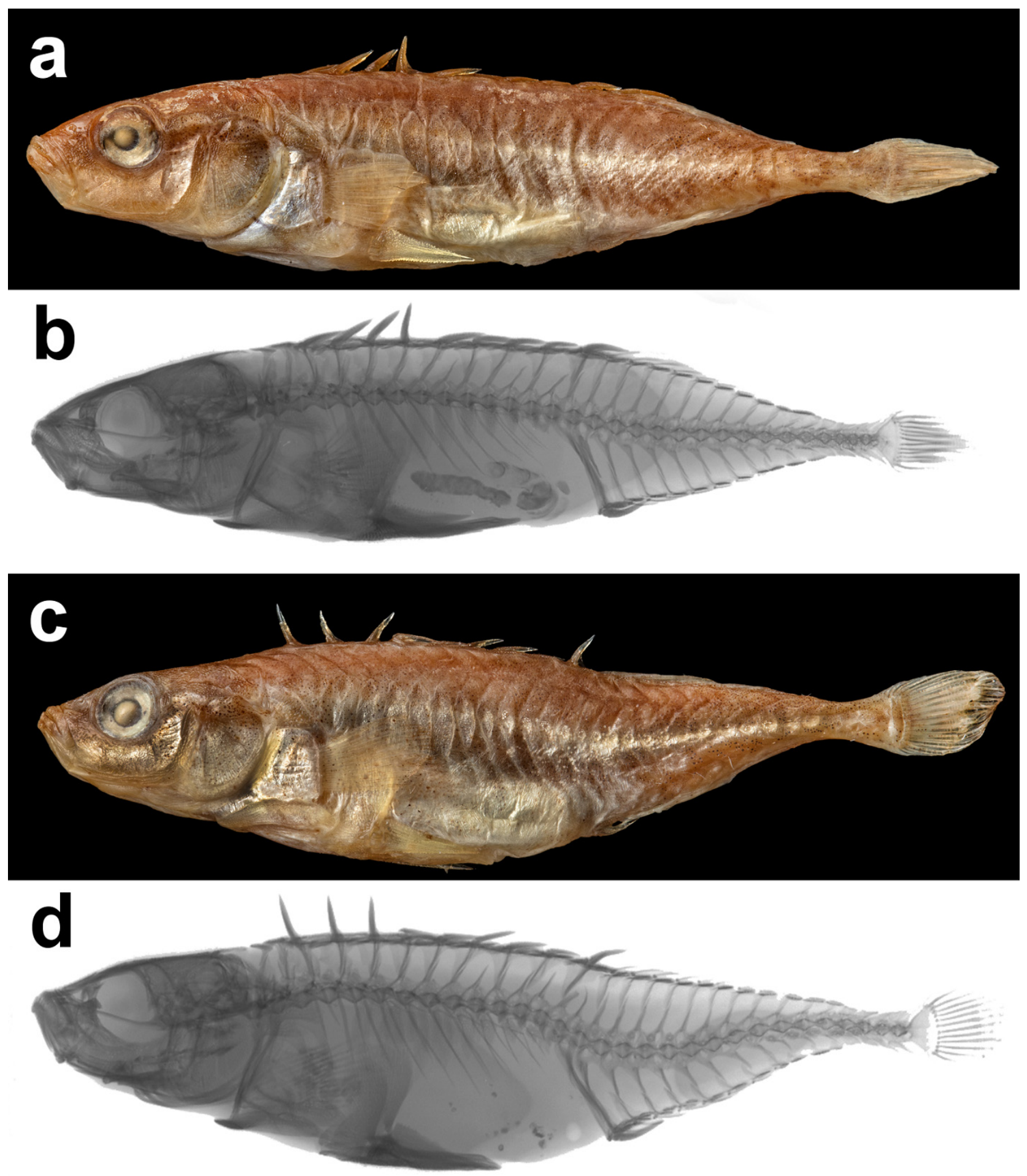

FIGURE 5. a) Syntypes of Gasterosteus platygaster Kessler, 1859, BMNH 1897.7.5.2, 44.4 mm SL. b) X-ray photograph of syntypes of G. platygaster, 44.4 mm SL. c) Syntypes of G. platygaster Kessler, 1859, BMNH 1897.7.5.2, 39.3 mm SL. d) X-ray photograph of syntypes of $G$. platygaster, $39.3 \mathrm{~mm} \mathrm{SL}$.

We obtained photographs and counts of syntypes of Gasterosteus stenurus through help of Anastasia Yurtseva of ZIN (Fig. 7). The morphological data clearly differentiate Pungitius modestus from P. stenurus by its lateral plates (small and unconnected, and running from just behind the dorsal end of the gill opening to the posterior side of the caudal peduncle, vs. large connected lateral plates), the smaller number of anal-fin rays (7-10 [usually 8], vs. 9-10), and the first dorsal-fin spine above or behind the pectoral-fin base (vs. in front of the pectoral-fin base). 


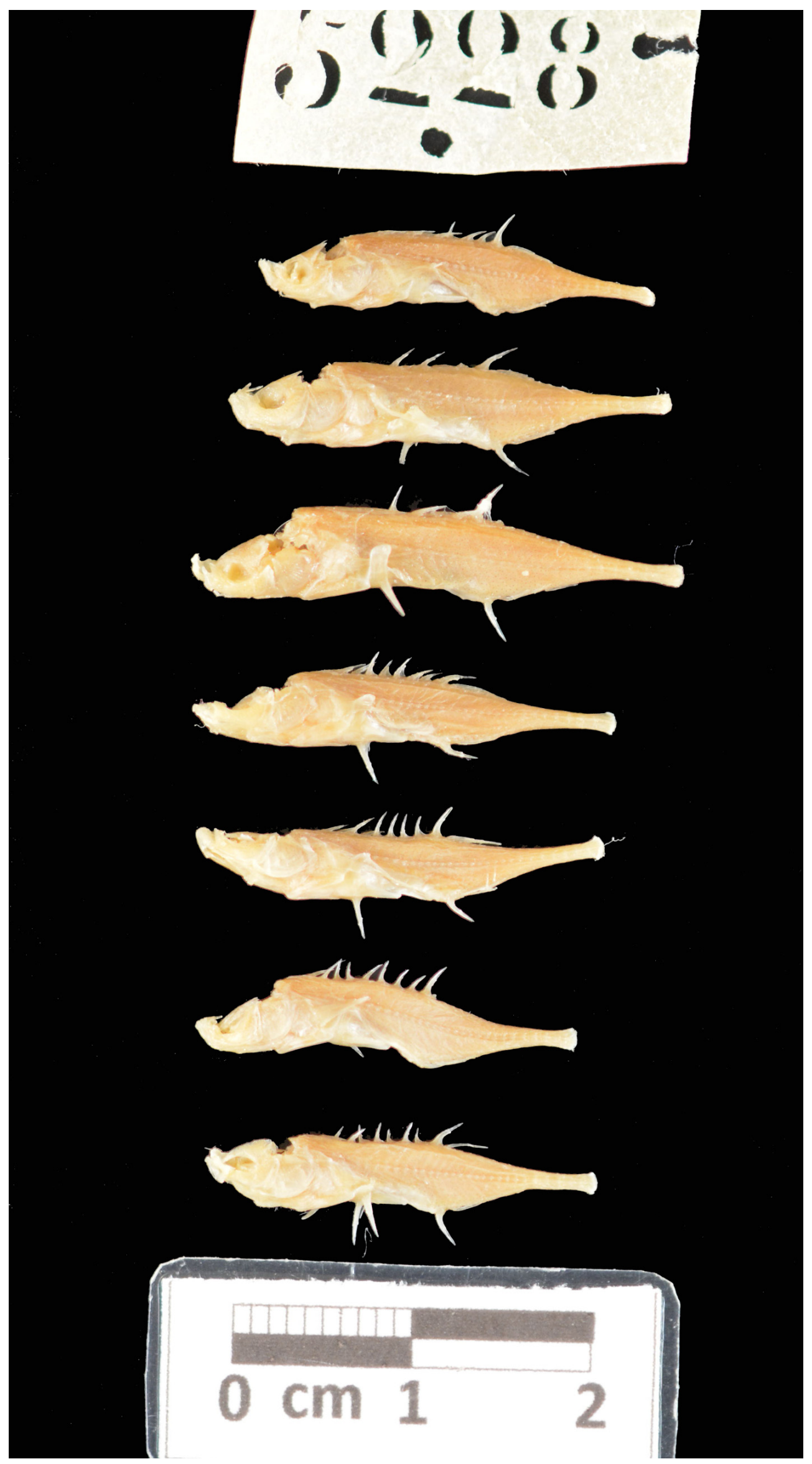

FIGURE 6. Syntypes of Gasterosteus sinensis Guichenot, 1869, MNHN 0000-5228, 21-26 mm SL. 


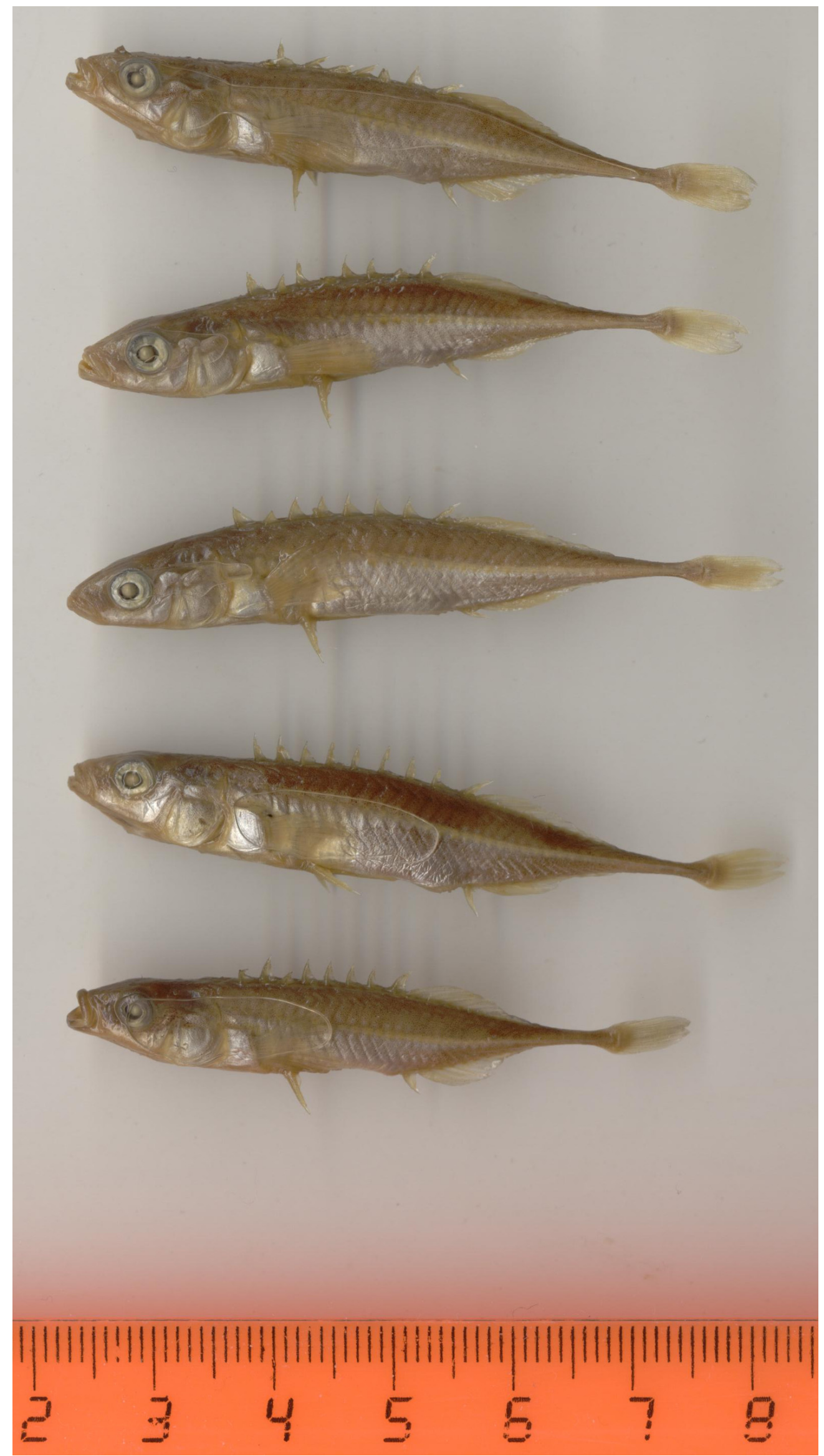

FIGURE 7. Syntypes of Gasterosteus stenurus Kessler, 1876, ZIN 2471, 46-55 mm SL. 


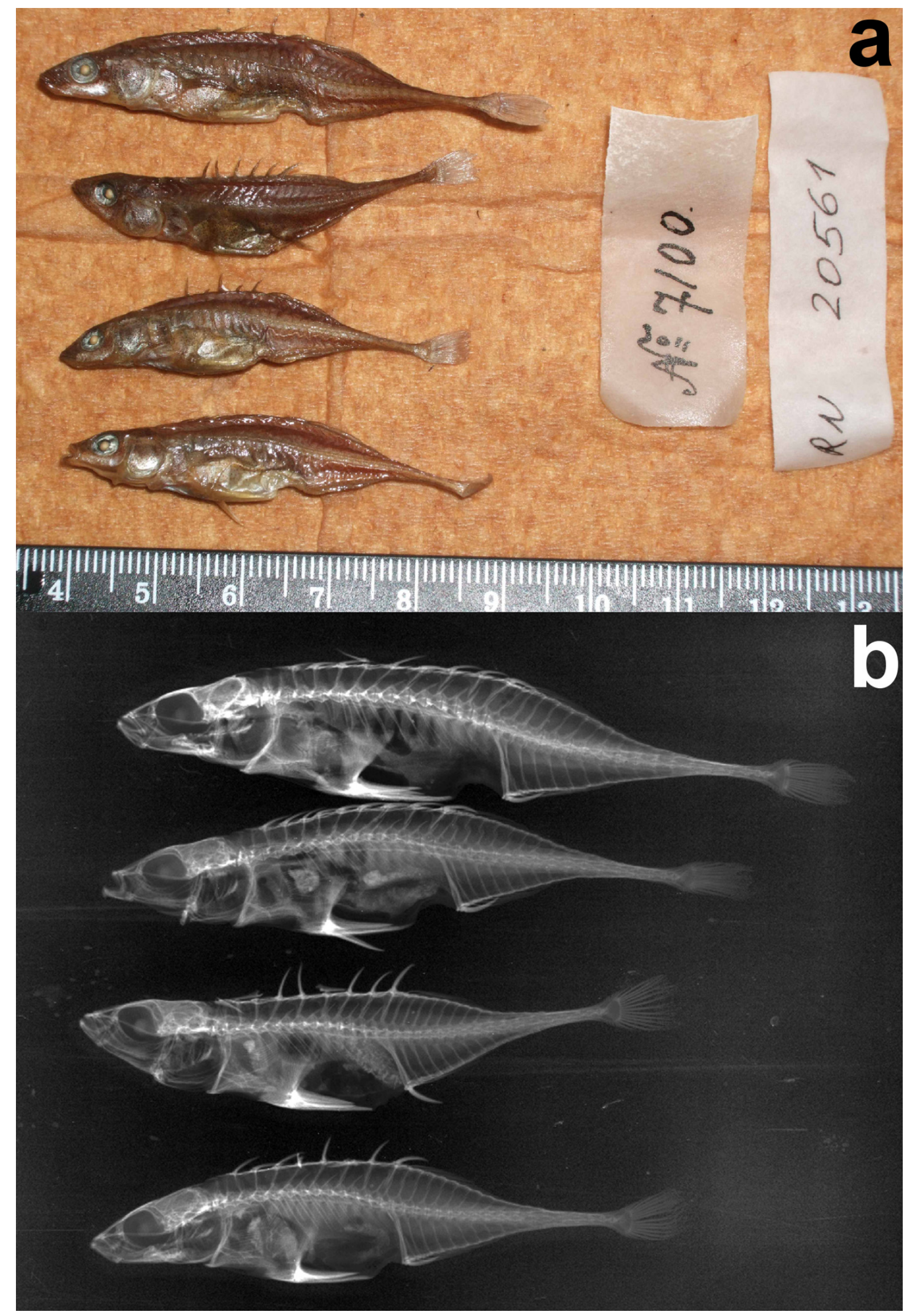

FIGURE 8. a) Syntypes of Gasterosteus bussei Warpachowski, 1888, ZIN 7100, 42-53 mm SL. b) X-ray photograph of syntypes of G. bussei. 
TABLE 4. Proportional measurements of type specimens of Pungitius modestus, sp. nov. expressed as percentages of standard length and head length.

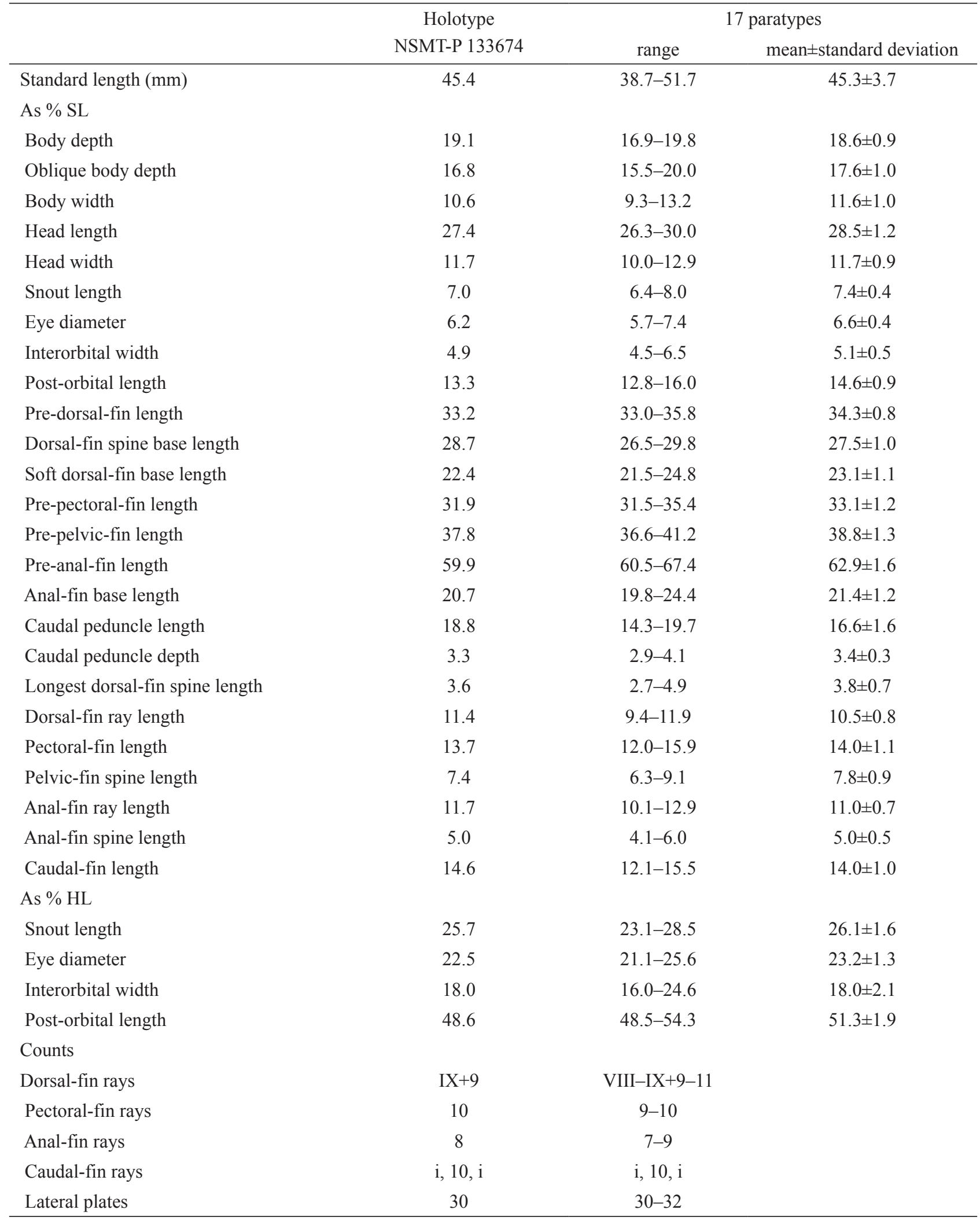

Staff members of ZIN attempted to locate four syntypes (ZIN 7100) of Gasterosteus bussei, but unfortunately, they were missing. However, Hiroshi Takahashi of the National Fisheries University in Japan was able to provide a photograph and X-ray of the syntypes (Fig. 8) sent to him from Valentina G. Sideleva of ZIN in 2017. The available morphological data differentiate Pungitius modestus from $P$. bussei by the first dorsal-fin spine located above 
or behind the pectoral-fin base (vs. in front of the pectoral-fin base), the lateral plates (small and unconnected, and running from just behind the dorsal end of the gill opening to the posterior side of the caudal peduncle, vs. large connected lateral plates), the longer pre-dorsal $(33.0 \%-35.8 \%$, vs. $27.0 \%-29.4 \% \mathrm{SL})$, the shorter base of the spiny dorsal fin $(26.5 \%-29.8 \%$, vs. $32.1 \%-33.5 \%$ SL), and the shorter pelvic-fin spine $(6.3 \%-9.1 \%$, vs. $10.0 \%-11.6 \%$ SL) and the longer caudal-fin (12.1\%-15.5\%, vs. $10.7 \%-10.9 \%$ SL).

TABLE 5. Proportional measurements and counts of type specimens of Pungitius kaibarae expressed as percentages of standard length and head length. Although all paratypes were examined, the proportional measurements of ZUMT 59852 are excluded from the table because it is shorter than $35 \mathrm{~mm}$ SL.

\begin{tabular}{|c|c|c|c|}
\hline & \multirow{2}{*}{$\begin{array}{c}\text { Holotype } \\
\text { ZUMT } 8197\end{array}$} & \multicolumn{2}{|c|}{7 paratypes } \\
\hline & & range & mean \pm standard deviation \\
\hline Standard length $(\mathrm{mm})$ & 45.0 & $39.4-45.0$ & $41.2 \pm 2.0$ \\
\hline \multicolumn{4}{|l|}{ As $\%$ SL } \\
\hline Body depth & 20.9 & $20.9-24.2$ & $22.8 \pm 1.4$ \\
\hline Oblique body depth & 18.7 & $16.9-23.0$ & $19.3 \pm 2.5$ \\
\hline Head length & 28.4 & $27.8-32.0$ & $29.7 \pm 1.5$ \\
\hline Snout length & 6.7 & $5.8-8.7$ & $7.3 \pm 1.0$ \\
\hline Eye diameter & 6.2 & $6.2-9.3$ & $7.9 \pm 0.7$ \\
\hline Post-orbital length & 14.7 & $13.8-16.9$ & $15.4 \pm 1.2$ \\
\hline Pre-dorsal-fin length & 30.0 & $25.9-30.8$ & $28.7 \pm 2.1$ \\
\hline Dorsal-fin spine base length & 32.0 & $28.0-36.3$ & $32.7 \pm 3.6$ \\
\hline Soft dorsal-fin base length & 23.3 & $21.5-28.3$ & $25.3 \pm 2.5$ \\
\hline Pre-pectoral-fin length & 31.1 & $29.5-33.8$ & $31.4 \pm 1.9$ \\
\hline Pre-pelvic-fin length & 35.3 & $36.3-40.7$ & $38.9 \pm 1.7$ \\
\hline Pre-anal-fin length & 54.7 & $60.0-61.9$ & $60.7 \pm 0.8$ \\
\hline Anal-fin base length & 23.8 & $24.0-26.8$ & $25.2 \pm 1.1$ \\
\hline Caudal peduncle length & 21.3 & $14.5-16.8$ & $15.6 \pm 0.6$ \\
\hline Caudal peduncle depth & 2.9 & $2.7-3.6$ & $3.2 \pm 0.3$ \\
\hline Pectoral-fin length & 14.7 & $14.2-16.0$ & $14.9 \pm 0.6$ \\
\hline Pelvic-fin spine length & 10.9 & $8.2-13.3$ & $11.0 \pm 1.7$ \\
\hline \multicolumn{4}{|l|}{ As $\% \mathrm{HL}$} \\
\hline Snout length & 23.4 & $18.5-30.0$ & $24.7 \pm 4.1$ \\
\hline Eye diameter & 21.9 & $23.2-29.8$ & $26.4 \pm 2.3$ \\
\hline Post-orbital length & 51.6 & $47.5-56.7$ & $51.9 \pm 3.1$ \\
\hline \multicolumn{4}{|l|}{ Counts } \\
\hline Dorsal-fin rays & $\mathrm{VIII}+9$ & VIII-IX+9-11 & \\
\hline Pectoral-fin rays & 10 & 10 & \\
\hline Anal-fin rays & $\mathrm{I}, 8$ & $\mathrm{I}, 8-9$ & \\
\hline Caudal-fin rays & $\mathrm{i}, 10, \mathrm{i}$ & $\mathrm{i}, 10, \mathrm{i}$ & \\
\hline Lateral plates & 32 & $32-34$ & \\
\hline
\end{tabular}

James Maclaine of BMNH kindly provided us with photographs and morphological data of syntypes of Gasterosteus tymensis (Fig. 9). This plus the characteristics of Pungitius tymensis provided in Keivany \& Nelson (2000) and Shedko et al. (2005) differentiate P. modestus from P. tymensis by its lateral plates (small and unconnected, and running from just behind the dorsal end of gill opening to the posterior side of the caudal peduncle, vs. several lateral plates in the area just behind the end of the gill opening and the caudal peduncle only), the smaller number of dorsal-fin spines (VIII-X, vs. VIII-XIII), the smaller number of anal-fin rays (7-10, vs. 8-12), the ascending process of the pelvis (relatively developed and extending dorsally to the level of the dorsal-most actinost, vs. less developed and smaller). 

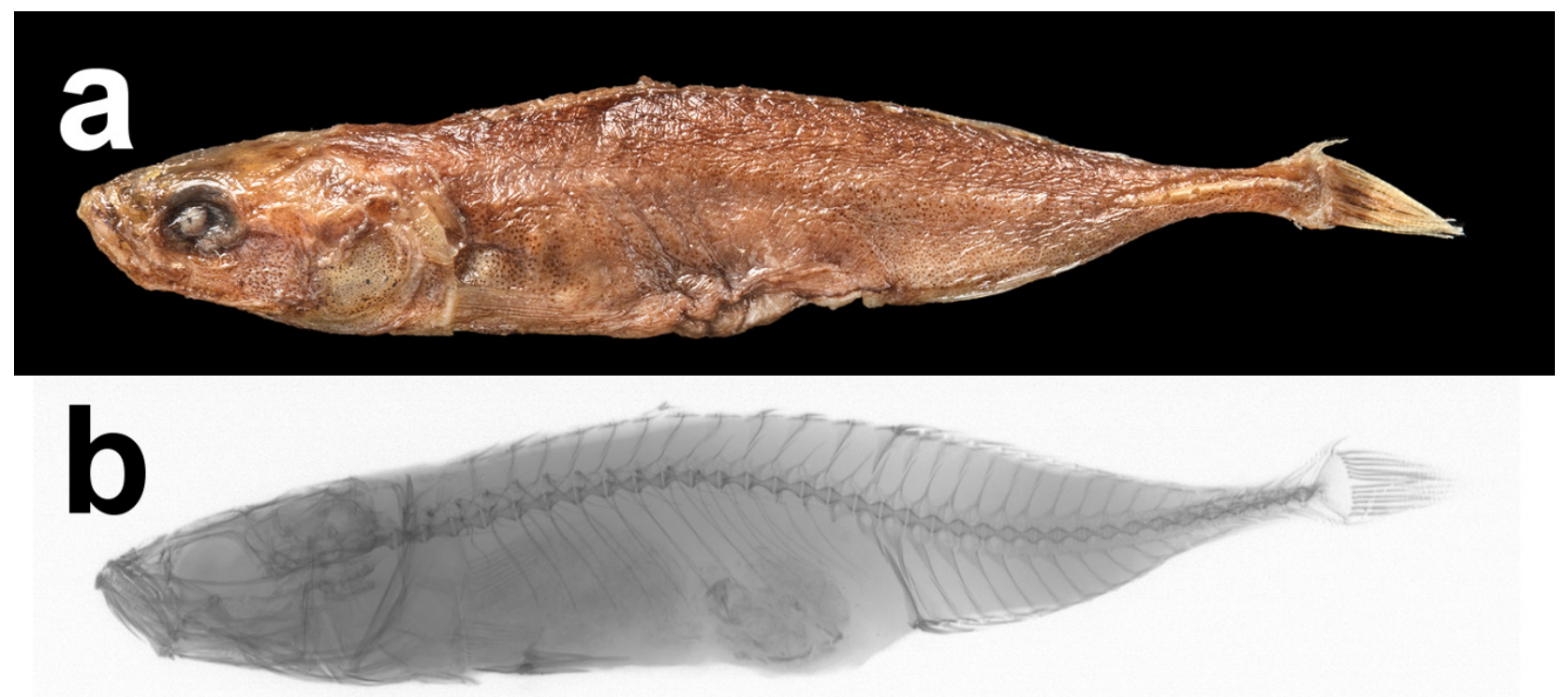

FIGURE 9. a) Syntype of Gasterosteus tymensis Nikolski, 1889, BMNH 1892.4.28, 58.5 mm SL. b) X-ray photograph of syntype of G. tymensis.

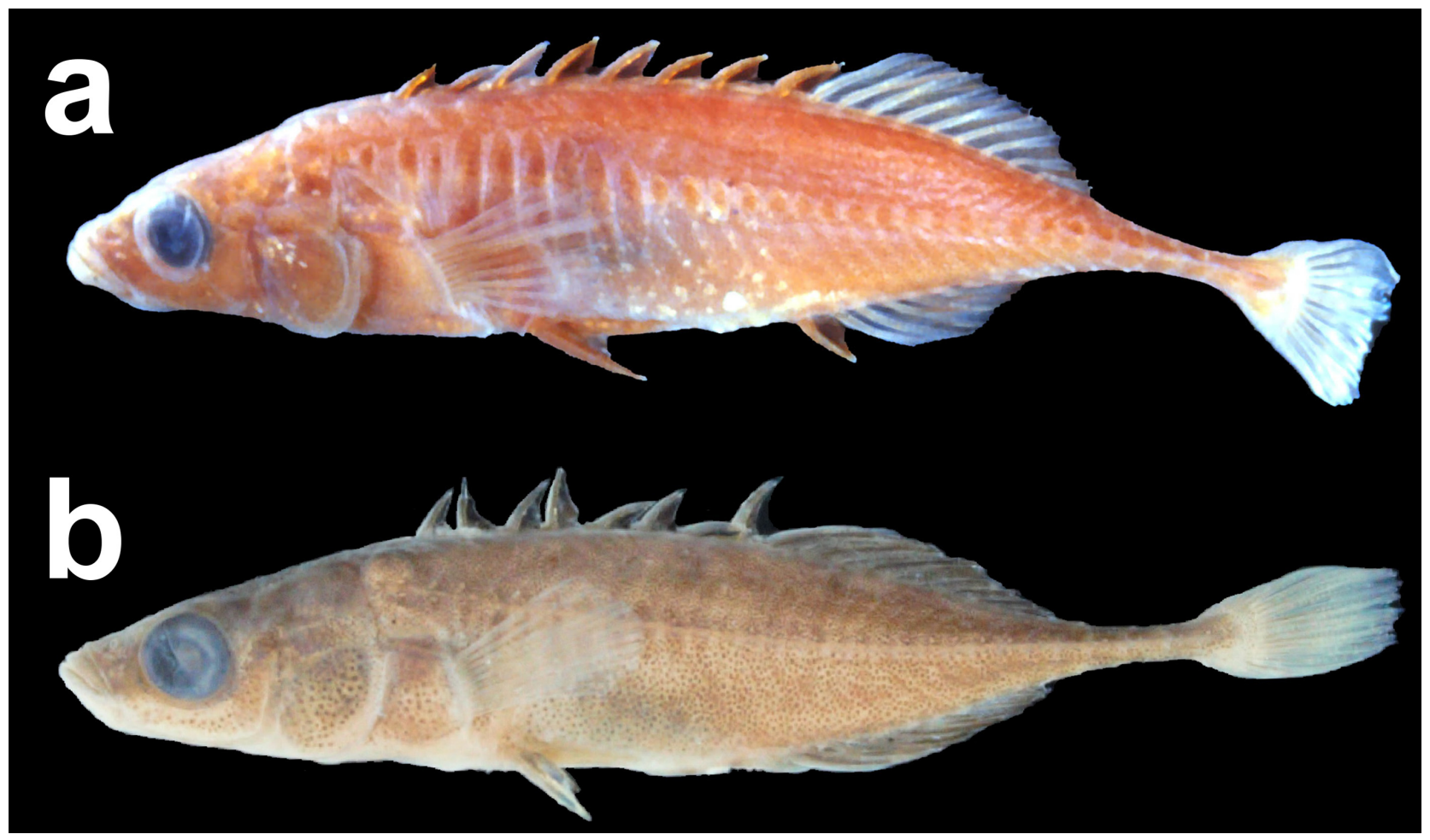

FIGURE 10. a) Holotype of Pygosteus kaibarae Tanaka, 1915, ZUMT 8197, 45.0 mm SL (photographed by K. Hosoya). b) Pungitius kaibarae from Korea, NSMT-P 140556, 31.8 mm SL, Gangneung, Gangwon-do, Korea.

Within the genus Pungitius, P. modestus is most similar to P. kaibarae, which was described by Tanaka (1915) based on the type specimens collected from Kyoto Prefecture (Fig. 10a). Since this original description, this species has also been collected from Hyogo, Kyoto, and Osaka prefectures in Japan as well as from Korea (Tanaka et al. 1982, Chae and Yang 1993, Hosoya 2013, Bae and Suk 2015). Although all Japanese populations were extirpated in the period from the 1930s to 1950s (Hosoya 2018), the species is still found along the eastern side of the Korean Peninsula (Bae \& Suk 2015) (Fig. 10b). However, Hosoya (2013) suggested that the Kyoto and Korean populations of $P$. kaibarae differ at the species level. Our examinations differentiate $P$. modestus from the type specimens of $P$. 
kaibarae (Table 5) and specimens from Korea by its lateral plates (small and unconnected, and running from just behind the dorsal end of gill opening to the posterior side of the caudal peduncle, vs. large connected lateral plates) (Fig. 11a-c), the location of the first dorsal-fin spine (behind, vs. in front of the pectoral-fin base) (Fig. 12a-c), the larger number of dorsal-fin spines (VIII-X [usually IX], vs. VIII-IX [usually VIII]) and the larger number of anal-fin rays (7-10 [usually 8], vs. 8-9 [usually 9]), the shorter base of the spiny dorsal fin ( $26.5 \%-29.8 \%$, vs. $28.0 \%-36.3 \% \mathrm{SL})$, the longer pre-anal fin $(59.9 \%-67.4 \%$, vs. $54.7 \%-61.9 \% \mathrm{SL})$ and the anal-fin spine below the 1 st-3rd dorsal-fin rays (vs. below or in front of the 1 st dorsal-fin ray), the shorter pelvic-fin spine $(6.3 \%-9.1 \%$, vs. $8.2 \%-13.3 \% \mathrm{SL}$ ), and dark brown membranes of spiny dorsal fin (vs. black).

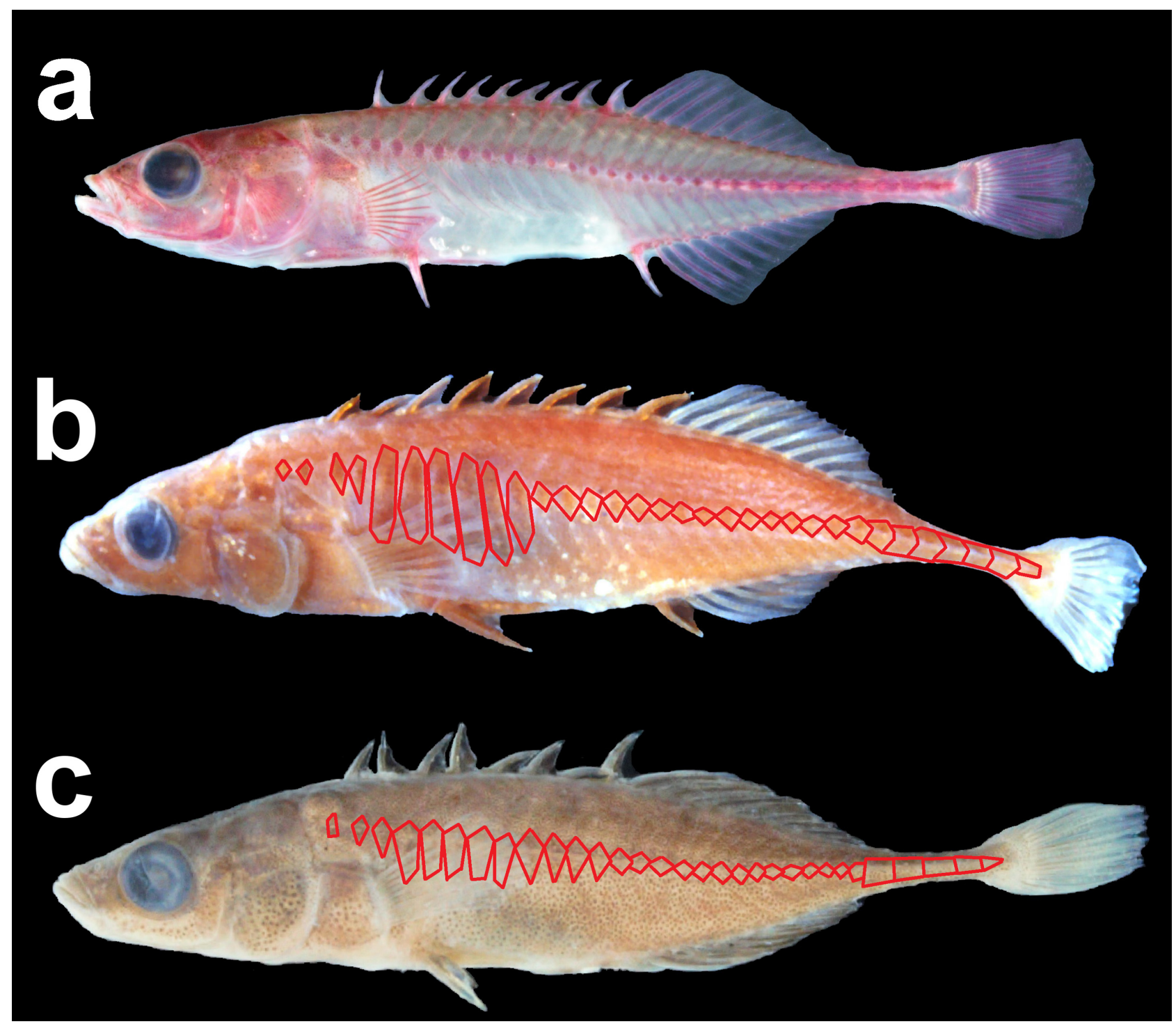

FIGURE 11. Comparisons of lateral plates of Pungitius modestus and P. kaibarae. a) Pungitius modestus, sp. nov., paratype, NSMT-P 140554, 40.5 mm SL. b) P. kaibarae, holotype, ZUMT 8197, $45.0 \mathrm{~mm}$ SL. c) P. kaibarae from Korea, non-type, NSMT-P 140556, $31.8 \mathrm{~mm}$ SL. Edges of the lateral plates are shown in red.

Keivany et al. (1997) re-described in detail Pungitius hellenicus, which is restricted to central Greece. In addition, its color was detailed in Keivany \& Nelson (2000). Pungitius modestus differs from P. hellenicus by VIII-X dorsal-fin spines inclining alternately left and right along the mid-line (vs. II-VI dorsal-fin spines vertically arranged), a keel on the caudal peduncle (vs. no keel), a lack of markings on the body (vs. dark bars or blotches on the body), dark brown membranes of spiny dorsal fin (vs. hyaline), the presence of the anteroventral process of the ectocoracoid (vs. absence of the anteroventral process of the ectocoracoid), and the presence of a pelvic girdle (vs. absence of a pelvic girdle). 
Shedko et al. (2005) described Pungitius polyakovi based on the holotype and 25 paratypes collected from southeastern Sakhalin Island, Russia. Their detailed description clearly differentiates $P$. modestus from P. polyakovi by the larger number of lateral plates (30-32, vs. 4-6), the smaller number of dorsal-fin spines (VIII-X [usually IX], vs. VIII-XI [usually X]), smaller dorsal-fin rays (9-11, vs. 10-12), the smaller number of anal-fin rays (7-10, vs. 9-11); the longer caudal peduncle $(14.3 \%-19.7 \%$, vs. $7.8 \%-11.6 \%$ SL); the lack of markings on the body (vs. 4-8 transverse brown bars on the body); in the breeding season, blackening of the entire male body (vs. blackening of only the ventral side of the head and body); the presence of the anteroventral process of the ectocoracoid (vs. absence of the anteroventral process of the ectocoracoid); articulation of the right and left ectocoracoids at the anterior end (vs. no articulation of the right and left ectocoracoids); and the ascending process of the pelvis (extending dorsally to the level of the dorsal-most actinost, vs. less developed and smaller).

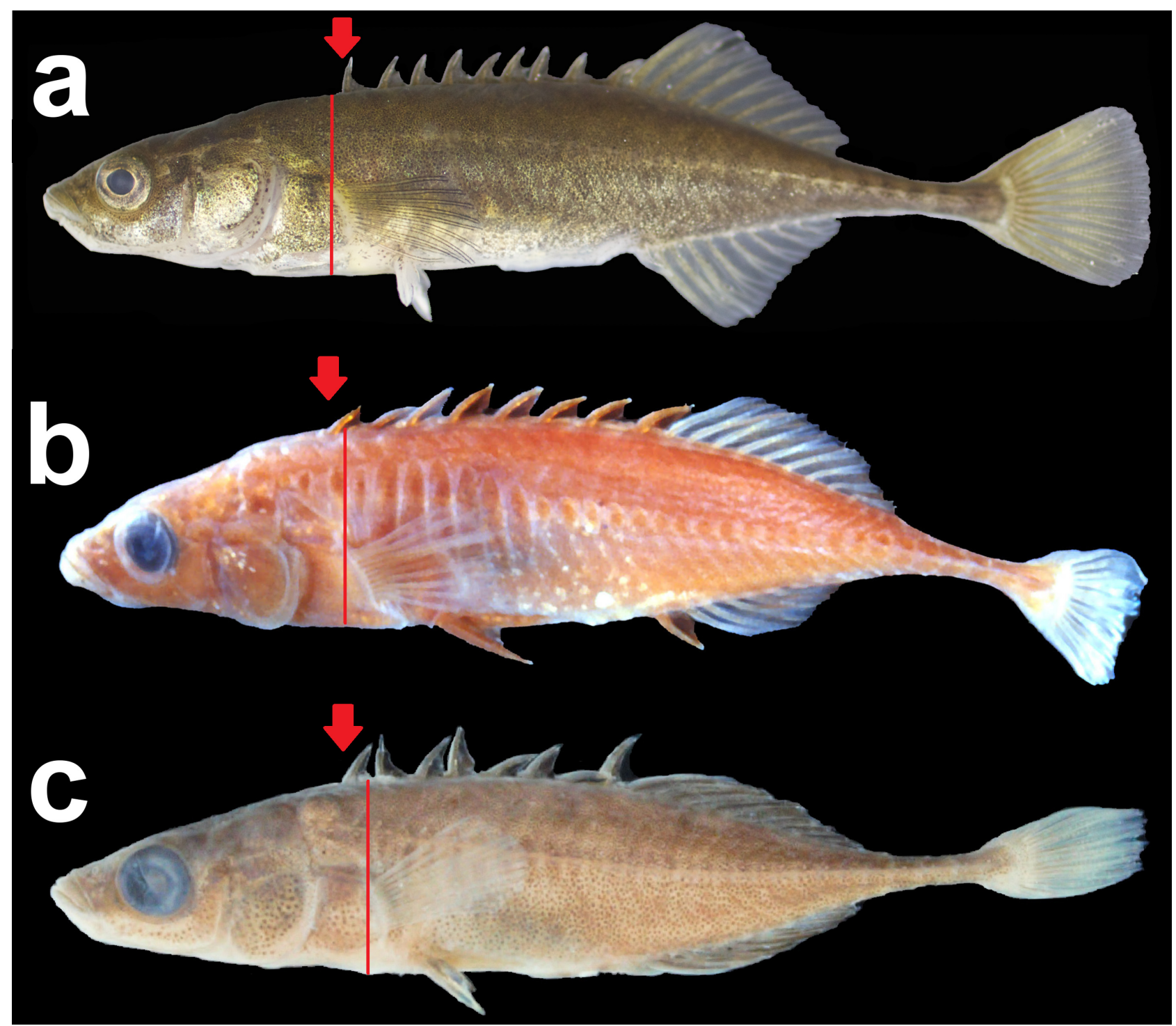

FIGURE 12. Comparisons of the origin of the spiny dorsal fin in Pungitius modestus and P. kaibarae. a) Pungitius modestus, sp. nov., holotype, NSMT-P 133674, 45.4 mm SL. b) P. kaibarae, holotype, ZUMT 8197, 45.0 mm SL. c) P. kaibarae from Korea, non-type, NSMT-P 140556, $31.8 \mathrm{~mm}$ SL. The first dorsal-fin spine is shown by a red arrow, and the origin of the pectoral-fin base is shown by a red vertical line.

\section{Acknowledgments}

We are grateful to the following persons and institutions for providing us with photographs and morphological data of Pungitius specimens: James Maclaine (BMNH), Jonathan Pfliger (MNHN), Hiroshi Takahashi (National Fisher- 
ies University, Shimonoseki), Masaaki Honma (YAMA); Miyuki Oshino (YUMB), Anastasia Yurtseva (ZIN), and Kazumi Hosoya (Kindai University, Nara). We also thank Kazuo Sakamoto (ZUMT) for granting the second author use of the facility during his visit, and Takayoshi Takeda (Yamagata Prefecture) for kindly taking photographs of the living specimens of $P$. modestus and for sharing his observational records of the nocturnal spawning behavior of $P$. modestus. We also thank Ko Tomikawa (Hiroshima University, Hiroshima) for identifying Jesogammarus jesoensis, the main food of $P$. modestus, and the government of Yamagata Prefecture for permitting us to collect $P$. modestus from protected habitats within the prefecture. We also thank two anonymous reviewers for comments that helped improve this paper. This study was partially supported by JSPS KAKENHI (No. 23570105).

\section{References}

Bae, H.-G. \& Suk, H.Y. (2015) Population genetic structure and colonization history of short ninespine sticklebacks (Pungitius kaibarae). Ecology and Evolution, 5, 3075-3089.

https://doi.org/10.1002/ece3.1594

Blanchard, C.E. (1866) Les poissons des eaux douces de la France: Anatomie, physiologie, description des espèces, mœurs, instincts, industrie, commerce, ressources alimentaires, pisciculture, législation concernant la pêche. Baillère, Paris, xvi +656 pp. https://doi.org/10.5962/bhl.title.5776

Chae, B.-S. \& Yang, H.-J. (1993) Spawning and growth of eight spine stickleback, Pungitius sinensis kaibarae (Tanaka) (Gasterosteidae, Pisces), in the Chayang Stream, a tributary of Kumho River, Korea. Korean Journal of Zoology, 36, $181-192$.

Coste, P. (1848) Nidification des épinoches et des épinochettes. Mémoires Présentés par Divers Savants à l'Académie des Sciences de l'Institut National de France, Sciences Mathématiques et Physiques, 10, 575-588, 1 pl.

Cuvier, G. (1829) Le rel̀gne animal distribueì d'apreÌs son organisation, pour servir de base aÌ l'histoire naturelle des animaux et d'introduction aİ l'anatomie compareie. Vol. 2. Nouvelle Edition. Chez Déterville, Paris, 406 pp. https://doi.org/10.5962/bhl.title.49223

Denys, G.P.J., Persat, H., Dettai, A., Geiger, M.F., Freyhof, J. \& Keith, P. (2018) Genetic and morphological discrimination of three species of ninespined stickleback Pungitius spp. (Teleostei, Gasterosteidae) in France with validation of Pungitius vulgaris (Mauduyt, 1848). Journal of Zoological Systematics and Evolutionary Research, 56 (1), 77-101. https://doi.org/10.1111/jzs.12178

Fricke, R., Eschmeyer, W.N. \& Van der Laan, R. (Eds.) (2020) Eschmeyer's catalog of fishes: genera, species, references. Electronic version. Available from: http://researcharchive.calacademy.org/research/ichthyology/catalog/fishcatmain.asp (accessed 12 May 2020)

Guichenot, A. (1869) Notice sur quelques poissons inédits de Madagascar et de la Chine. Nouvelles Archives du Muséum d'Histoire Naturelle, Série 2, 5 (Fasc. 3), 193-206, pl. 12.

Hanzawa, N., Honma, M., Suzuki, Y. \& Hida, Y. (2019) Red list of freshwater fishes in Yamagata Prefecture. In: Yamagata Prefectural Government (Eds.), Red data book 2019 of Yamagata Prefecture-Endangered species in Yamagata Prefecture. Yamagata Prefectural Government, Yamagata, pp. 131-162.

Hart, P.J.B. (2003) Habitat use and feeding behaviour in two closely related fish species, the three-spined and nine-spined stickleback: an experimental analysis. Journal of Animal Ecology, 72, 777-783. https://doi.org/10.1046/j.1365-2656.2003.00747.x

Hashimoto, K. (1938) Freshwater fishes in Yamagata Prefecture. Yamagataken kyoikukai, Yamagata, 15 pp.

Hosoya, K. (2013) Pungitius kaibarae. In: Nakabo, T. (Ed.), Fishes of Japan with pictorial keys to species. $3^{\text {rd }}$ Edition. Tokai University Press, Hadano, pp. $607+1904$.

Hosoya, K. (2018) Pungitius kaibarae. In: Nakabo, T. (Ed.), The natural history of the fishes of Japan. Shogakukan Inc, Tokyo, pp. 185.

Hubbs, C.L. \& Lagler, K.F. (1964) Fishes of the Great Lakes region. University of Michigan press, Ann Arbor, Michigan, xi + 213 pp.

Ikeda, K. (1933) The distribution and variation of the Gasterosteidae in Japan. Zoological Magazine, 45, 141-173.

Keyvany, Y. \& Nelson, J.E. (2000) Taxonomic review of the genus Pungitius, ninespine sticklebacks (Gasterosteidae). Cybium, $24(2), 107-122$.

Keivany, Y., Nelson, J.E. \& Economidis, P.S. (1997) Validity of Pungitius hellenicus Stephanidis, 1971 (Teleostei, Gasterosteidae), a Stickleback Fish from Greece. Copeia, 1997 (3), 558-564. https://doi.org/10.2307/1447559

Kelly, W.L. \& Bryden, M.M. (1983) A modified differential stain for cartilage and bone in whole mount preparations of mammalian fetuses and small vertebrates. Stain Technology, 58, 131-134. https://doi.org/10.3109/10520298309066773

Kessler, K.F. (1859) II. Systematische Uebersicht der Stachelflosser (Acanthopteri Müller), welche im nordwestlichen Theile des schwarzen Meeres und in den Mündungen der in derselben sich ergiessenden südrussischen Flüsse vorkommen. Bulletin de la Société Impériale des Naturalistes de Moscou, 32 (3), 186-268. 
Kessler, K.F. (1876) Ryby. In: Prejeval'skii, N.M. (Ed.), Mongoliya i strana tangutov', St. Petersburg, 2 (4), pp. 6-9.

Linnaeus, C. (1758) Systema Naturae. Ed. X. Systema naturae per regna tria naturae, secundum classes, ordines, genera, species, cum characteribus, diferentiis, synonymis, locis. Tomus I. Editio decima, reformata. Laurentii Salvii, Holmiae, ii + $824 \mathrm{pp}$. https://doi.org/10.5962/bhl.title.542

Mauduyt, F. (1848) Ichthyologie de la Vienne, ou tableau méthodique et descriptif des poissons qui vivent habituellement dans les eaux de ce département ou qui y remontent périodiquement et accidentellement. Bulletin de la Société Académique d'Agriculture, Belles-Lettres, Sciences et Arts, de Poitiers 1848, 3 (Fasc. 9-12), 8-49.

Meguro, Y., Takahashi, H., Machida, Y., Shirakawa, H., Michelle, R. Gaither, M.R. \& Goto, A. (2016) Assortative mating and divergent male courtship behaviours between two cryptic species of nine-spined sticklebacks (genus Pungitius). Behaviour, 153, 1879-1911. https://doi.org/10.1163/1568539X-00003396

Nikolskii, A.M. (1889) Sakhalin Island and its fauna of vertebarate animals. Supplement to Memoirs of Academy of Science, St. Petersburg, Series 7, 60 (5), pp. 292-305.

Shedko, S.V., Shedko, M.B. \& Pietsch, T.W. (2005) Pungitius polyakovi sp. n.-New species of the ninespine stickleback (Gasterosteiformes, Gasterosteidae) from the south-eastern of the Sakhalin Island. In: Flora and Fauna of Sakhalin Island. Part 2. Dalnauka, Vladivostok, pp. 223-233.

Stephanidis, A. (1971) Epi merikon ichthyon ton gaukeon tiz Ellados [On some freshwater fishes from Greece]. Biologia GalloHellenica, 3, 213-241. [in Greek with English and French summaries]

Takahashi, H., Møller, P.R., Shedko, S.V., Ramatulla, T., Joen, S.R., Zhang, C.G., Sideleva, V.G., Takata, K., Sakai, H., Goto, A. \& Nishida, M. (2016) Species phylogeny and diversification process of Northeast Asian Pungitius revealed by AFLP and mtDNA markers. Molecular Phylogenetics and Evolution, 99, 44-52. https://doi.org/10.1016/j.ympev.2016.03.022

Takahashi, H., Takata, K. \& Goto, A. (2001) Phylogeography of lateral plate dimorphism in the freshwater type of ninespine sticklebacks, genus Pungitius. Ichthyological Research, 48 (2), 143-154. https://doi.org/10.1007/s10228-001-8129-2

Takata, K., Goto, A. \& Yamazaki, F. (1987a) Biochemical identification of a brackish water type of Pungitius pungitius, and its morphological and ecological features in Hokkaido, Japan. Japanese Journal of Ichthyology, 34 (2), 176-183. https://doi.org/10.1007/BF02912412

Takata, K., Goto, A. \& Yamazaki, F. (1987b) Genetic differences of Pungitius pungitius and P. sinensis in a small pond of the Omono River system. Japanese Journal of Ichthyology, 34 (3), 384-386. https://doi.org/10.1007/BF03380129

Tanaka, S. (1915) Ten new species of Japanese fishes. Doubutsugaku Zasshi (Zoological Magazine), 27, 565-568.

Tanaka, S., Hirai, K. \& Jeon, S.-R. (1982) Morphological comparisons of Korean and Japanese specimens of Pungitius kaibarae. Tansuigyo (Freshwater Fishes), 8, 71-72.

Tanaka, S. (1982) Variations in ninespine sticklebacks, Pungitius pungitius and P. sinensis, in Honshu, Japan. Japanese Journal of Ichthyology, 29, 203-212.

Wang, C., Shikano, T., Persat, H. \& Merilä, J. (2015) Mitochondrial phylogeography and cryptic divergence in the stickleback genus Pungitius. Journal of Biogeography, 2015, 1-15.

Warpachowski, N.A. \& Herzenstein, S.M. (1888) Notizen über die Fischfauna des Amur-Beckens und der angrenzenden Gebiete. Trudy St.Peterburgskogo Obscestva Estestvoispytatelej, 19 (8), 1-58, 1 pl.

Wootton, R.J. (1976) The biology of the sticklebacks. Academic Press, London, $\mathrm{x}+387$ pp. 